\title{
Impacto de los diarios digitales en la votación electoral
}

David Paz Panduro ${ }^{1}$

\begin{abstract}
RESUMEN
El presente artículo tiene como finalidad demostrar que las menciones de los candidatos políticos en los diarios digitales tienen una correlación positiva con la votación electoral. Asimismo, el indicador de la variable independiente usado es el número de noticias en el que son nombrados los candidatos políticos en la prensa digital; mientras que el indicador de la variable dependiente es el porcentaje de la votación electoral obtenido por los candidatos políticos. El proceso electoral analizado fueron las elecciones municipales para Lima Metropolitana 2018. Además, se ha utilizado el buscador Google, donde se usó el comando básico (operador de búsqueda) site para buscar en las webs de 19 diarios digitales peruanos las menciones de los candidatos de manera semimanual. Finalmente, se obtuvo como resultado que los diarios digitales tienen una correlación muy fuerte con la votación electoral, pues el rho de Spearman es de 0,933.
\end{abstract}

Palabras-claves: Marketing digital; votación electoral; marketing político; marketing político digital.

\section{INTRODUCCIÓN}

En el Perú, existe un problema de percepción. Según la encuesta CPI mencionada en el diario El Comercio (26 de agosto de 2014), los partidos políticos son corruptos; el APRA, Perú Posible y Fuerza Popular son los partidos que han obtenido el más alto porcentaje en la respuesta a «¿cuál es el partido más corrupto?». En abril del 2018, según la encuesta de El Comercio (22 de abril de 2018) e Ipsos Perú, la corrupción ahora encabeza los problemas del país. Esta situación no se repetía desde el 2010, durante el segundo gobierno aprista. El Perú ha descendido en el ranking global de percepción como uno de los países más corruptos, y comparte la posición 105 con los países El Salvador, Timor Oriental y Zambia (El Comercio, 29 de enero de 2019). Pese a que el nombre oficial del año 2019 en el Perú es «Año de la lucha contra la corrupción e impunidad», la percepción en las mentes de los peruanos es el problema del presente estudio.

En las siguientes líneas se pretende evidenciar cómo los diarios digitales, que forman parte de las herramientas de la mercadotecnia digital, están asociados con la votación electoral, es decir, al resultado en las urnas, que es el juicio final que da un pueblo sobre los candidatos políticos y los partidos que los respaldan. Por lo tanto, el aporte del presente estudio consiste en demostrar, estadísticamente, que los diarios digitales están asociados a la votación electoral y en conocer cuál es el indicador que muestra esta correlación.

Nuestro artículo fue elaborado para contribuir con los partidos políticos en plantear su estrategia de mercadotecnia; por lo tanto, la orientación de este estudio es de B2B (Business to Business), considerando al autor de esta investigación como una empresa que ofrece esta información a los partidos políticos, los cuales se manejan actualmente como empresas privadas. De esta manera, los directores de la campaña política (gerentes de proyecto) podrán orientar sus estrategias a incrementar los indicadores que están correlacionados con la votación en las urnas, debido a que se demuestra que si se aumentan estos indicadores también aumenta la votación electoral.

1 Ingeniero industrial por la Universidad Nacional Mayor de San Marcos. Actualmente, es jefe de Multiservicios Paz Panduro S. A. C. (Lima).

E-mail: paz.david.anibal@gmail.com 
En el Perú, el historiador Alfonso Quiroz, autor de Historia de la corrupción en el Perú (2013), menciona a algunos personajes como luchadores contra la ilegalidad, entre los que destacan Antonio de Ulloa, Domingo Elías y Manuel Gonzáles Prada (El Comercio, 11 de enero del 2019). A través de los diarios digitales, se podrá mostrar al electorado que los partidos políticos han vuelto a sus raíces y que se han nutrido de la modernidad. También se probará que sus valores aún siguen siendo sólidos, que existen líderes como estos luchadores contra la ilegalidad, que la institución política está por encima de los errores de los candidatos presidenciales, que finalmente son solo líderes que pueden ser reemplazados y que se puede continuar con la ideología del partido, lo cual es importante.

El marketing político ha sido usado en varias campañas presidenciales en el mundo con resultados positivos. Las campañas políticas en todo el mundo están diseñando «estrategias en las que los electores son analizados como consumidores, sus preferencias, sus necesidades también, su personalidad y sus valores son convertidos en estadísticas que permiten a un grupo de orientadores políticos ofrecer un producto deseable, una idea o un candidato que responda a la demanda de los electores» (Deza, 2010, pp. 9-10).

\section{METODOLOGÍA}

Por un lado, Monje (2011) afirma que «cuando el objetivo principal del investigador es comprender el comportamiento humano en contextos naturales, el diseño será de manera inevitable no experimental o de carácter observacional» (p. 24). Por otro lado, Hernández et al. (2010) definen la «investigación no experimental como estudios que se realizan sin la manipulación deliberada de variables y en los que solo se observan los fenómenos en su ambiente natural para después analizarlos» (p. 149). Por lo tanto, el diseño de esta investigación es no experimental, ya que no se tiene control de las variables de la investigación, y las menciones en los diarios digitales solo pueden ser modificadas por los encargados de la gestión de la campaña de los candidatos políticos.

Asimismo, según Tamayo (2003):

A la investigación aplicada se le denomina también activa o dinámica, y se encuentra íntimamente ligada a la anterior, ya que depende de sus descubrimientos y aportes teóricos. Busca confrontar la teoría con la realidad. Es el estudio y aplicación de la investigación a problemas concretos, en circunstancias y características concretas. Esta forma de investigación se dirige a su aplicación inmediata y no al desarrollo de teorías. (p. 43)

La investigación de esta tesis es de tipo aplicativa, puesto que se orienta a resolver problemas, a su aplicación inmediata. Además, el nivel de la investigación es correlacional, porque medirá el grado de correlación estadística entre la herramienta de mercadotecnia política y la votación electoral.

Este trabajo tendrá características cuantitativas. A partir de ello, Bernal (2010) define que:

[El] método cuantitativo o método tradicional se fundamenta en la medición de las características de los fenómenos sociales, lo cual supone derivar de un marco conceptual pertinente al problema analizado, una serie de postulados que expresen relaciones entre las variables estudiadas de forma deductiva. Este método tiende a generalizar y normalizar resultados. (p. 60)

El enfoque es hipotético-deductivo, porque se trata de desarrollar una teoría; se empieza por formular hipótesis básicas, para luego deducir sus consecuencias con la ayuda de las subyacentes teorías formales (Tamayo, 2003). La hipótesis que se ha formulado en el presente estudio es la de correlación entre los diarios digitales con la votación electoral, y se ha comprobado la relación existente mediante técnicas de estadística inferencial.

\section{Unidad de análisis}

El objeto de este estudio es el proceso electoral municipal de Lima Metropolitana 2018, en Lima (Perú). Se analizará la presencia de los candidatos políticos al sillón municipal en los diarios digitales, así como la relación de esta presencia con la votación electoral que alcanzaron en dicho proceso.

\section{Población de estudio}

Para este estudio, se ha elegido como población a todos los candidatos participantes de la elección municipal de Lima Metropolitana 2018. Además, se ha elegido este proceso por ser el más reciente en el Perú y porque, según la información de la nota de prensa del INEI (27 de marzo del 2018), en el primer semestre del 2018 accedieron a internet el $32,9 \%$ de los peruanos y el $56,7 \%$ de los ciudadanos de Lima Metropolitana; es decir, más de la mitad de los electores tuvieron acceso a internet. 


\section{Tamaño de muestra}

Los nueve candidatos al sillón municipal de Lima Metropolitana: Renzo Reggiardo, Daniel Urresti, Ricardo Belmont, Luis Castañeda Pardo, Jorge Muñoz, Humberto Lay, Esther Capuñay, Alberto Beingolea y Enrique Cornejo, son la muestra para probar la asociación entre las menciones de los candidatos políticos en los diarios digitales y la votación electoral.

\section{Selección de muestra}

La muestra seleccionada es no probabilística, ya que se ha elegido candidatos a analizar teniendo en cuenta sus posibilidades de acceso al sillón municipal y no de manera aleatoria. Asimismo, la votación de los candidatos seleccionados para este estudio cubre el $81,55 \%$ de la votación electoral; es decir, es un muestreo por juicio (Weiers, 1986).

En las muestras no probabilísticas, la elección de los elementos no depende de la probabilidad, sino de causas relacionadas con las características de la investigación o de quien hace la muestra. Aquí el procedimiento no es mecánico ni con base en fórmulas de probabilidad, sino que depende del proceso de toma de decisiones de un investigador o de un grupo de investigadores $y$, desde luego, las muestras seleccionadas obedecen a otros criterios de investigación. (Hernández et al., 2010, p. 176)

La muestra de los diarios digitales seleccionados para realizar el presente estudio está compuesta por los siguientes diecinueve diarios digitales: altavoz.pe, americatv.com.pe, andina.pe, atv.pe, canaln.pe, capital.com.pe, elcomercio.pe, diariocorreo.pe, elpopular.pe, enlinea.pe, exitosanoticias. pe, expreso.com.pe, gestion.pe, larepublica.pe, panamericana.pe, peru21.pe, rpp.pe, trome.pe y wayka.pe. Los diarios señalados se han elegido a partir de los reportes de Google Alerts, donde aparecen mencionando a los candidatos políticos que competían por el sillón municipal de Lima Metropolitana en la parte final del proceso electoral.

\section{Técnicas de recolección de datos}

Esta investigación ha utilizado la observación sistemática y las pruebas estadísticas, principalmente. Además, para analizar las menciones de los candidatos políticos en los diarios digitales en los últimos días de la campaña electoral municipal de Lima Metropolitana, se ha utilizado la opción de Alertas de Google, la cual proporciona todas las menciones de las palabras clave que se le suministra (en este caso, los nombres de los nueve candidatos). Estas menciones en internet fueron obtenidas cerca al día de la elección municipal (del 23 de setiembre al 6 de octubre del 2018, luego del debate municipal). Con esta información, se seleccionaron diecinueve diarios digitales.

Luego, para tabular el número de noticias por diario digital que menciona a cada uno de los candidatos políticos, se ha utilizado el buscador Google mediante el comando básico site (operador de búsqueda), el cual busca en una página web en particular un término o palabra clave. En este caso, ha permitido buscar las menciones de los candidatos políticos en sus noticias en cada página web de los diarios digitales seleccionados.

Después, para obtener el número de noticias de los diarios digitales que mencionan a un candidato, se ha tenido cuidado de no duplicar las noticias y se ha hecho una contabilización semimanual. Asimismo, se ha utilizado los resultados más relevantes que arroja la búsqueda de Google, omitiéndose las entradas muy similares.

La votación electoral alcanzada por los candidatos políticos analizados ha sido obtenida de la página web de la ONPE, el 2 de noviembre del 2018.

\section{ANÁLISIS E INTERPRETACIÓN DE LA INFOR- MACIÓN}

Para el procesamiento de datos, el estudio se apoya en el programa informático construido para ejecutar funciones estadísticas básicas y avanzadas: Minitab. También se ha utilizado Microsoft Excel para las tablas y otros gráficos personalizados. Además, para la interpretación de los estadísticos de resultado, se ha revisado los libros de Levin y Rubin (2004) y Webster (2000), así como la asistencia del Minitab.

\section{RESULTADOS Y DISCUSIÓN}

Se demostrará que la variable independiente Menciones de los candidatos políticos en la prensa digital está correlacionada estadísticamente, de manera alta, con la variable dependiente Votación electoral municipal Lima Metropolitana 2018.

Se ha obtenido el número de noticias, en las que son mencionados los candidatos políticos que competían al sillón municipal de Lima Metropolitana en el 2018, en la muestra de los diecinueve diarios digitales (ver tabla 1). 


\section{Correlación entre los indicadores Menciones de los candidatos políticos en la prensa digital y Votación electoral municipal Lima Metropolitana 2018}

En primer lugar, se establecerá si los indicadores Menciones de los candidatos políticos en la prensa digital y Votación electoral municipal Lima Metropolitana 2018 siguen una distribución normal. Así, se plantean las siguientes hipótesis:

N. ${ }^{\circ} 1$ hipótesis nula: la Votación electoral municipal Lima Metropolitana 2018 está distribuida normalmente.

A.1 hipótesis alternativa: la Votación electoral municipal Lima Metropolitana 2018 no está distribuida normalmente.

$\mathrm{N} .{ }^{\circ} 2$ hipótesis nula: el indicador Menciones de los candidatos políticos en la prensa digital y Número de noticias donde son mencionados los candidatos políticos en la prensa digital para las elecciones Lima 2018 están distribuidos normalmente.
A.2 hipótesis alternativa: el indicador Menciones de los candidatos políticos en la prensa digital y Número de noticias donde son mencionados los candidatos políticos en la prensa digital para las elecciones Lima 2018 no están distribuidos normalmente.

Se ha usado la prueba de normalidad de Shapiro-Wilk de acuerdo a lo recomendado por Guillén (2015), quien menciona que «debemos tener presente que se usa Kolgomorov Smirnov porque la muestra es mayor a 50, de no ser así se usa Shapiro Wilk» (p. 88), y por Milton (2001), quien enfatiza que «el test de Shapiro-Wilk es adecuado cuando hay pocos datos» (p. 640).

Por lo tanto, del informe proporcionado por SPSS y observado en la tabla 2 se tiene que el valor $p$ para la Votación electoral municipal Lima Metropolitana 2018 es menor al nivel de significancia 0,05. En ese sentido, se rechaza la hipótesis nula en el primer caso $\left(\mathrm{N} .{ }^{\circ} 1\right)$ y se acepta la primera hipótesis alternativa (A.1), en la que la Votación electoral municipal Lima Metropolitana 2018 no sigue una distribución normal.

Tabla 1. Indicador de menciones en los diarios digitales para los candidatos a las elecciones municipales Lima Metropolitana 2018.

\begin{tabular}{|l|c|c|}
\hline Candidato & Votación electoral (\%) & $\begin{array}{c}\text { Número de noticias donde son mencionados los candidatos } \\
\text { políticos en la prensa digital }\end{array}$ \\
\hline Jorge Muñoz & 36,03 & 781 \\
\hline Daniel Urresti & 19,69 & 1340 \\
\hline Renzo Reggiardo & 8,87 & 1019 \\
\hline Alberto Beingolea & 4,46 & 327 \\
\hline Ricardo Belmont Cassinelli & 3,89 & 706 \\
\hline Luis Castañeda Pardo & 2,58 & 303 \\
\hline Esther Capuñay & 2,04 & 207 \\
\hline Enrique Cornejo & 2,01 & 203 \\
\hline Humberto Lay & 1,98 & 158 \\
\hline
\end{tabular}

Fuente: elaboración propia.

Tabla 2. Prueba de normalidad de Shapiro-Wilk para Votación electoral municipal Lima Metropolitana 2018 y para Número de noticias donde son mencionados los candidatos políticos en la prensa digital para las elecciones Lima Metropolitana 2018.

\begin{tabular}{|l|c|c|c|c|c|c|}
\hline \multicolumn{2}{|c|}{ Pruebas de normalidad } \\
\hline
\end{tabular}

a: corrección de significación de Lilliefors.

Fuente: elaboración propia. 
El valor $\mathrm{p}$ para el Número de noticias donde son mencionados los candidatos políticos en la prensa digital es mayor al nivel de significancia 0,05. Por ello, se acepta la hipótesis nula en el segundo caso $\left(\mathrm{N} .{ }^{\circ} 2\right)$ y se rechaza la segunda hipótesis alternativa (A.2); es decir, el Número de noticias donde son mencionados los candidatos políticos en la prensa digital y el indicador de la variable Menciones de los candidatos políticos en la prensa digital sí siguen una distribución normal.

Sobre los coeficientes de correlación, Pérez (2001) indica que

Para las variables cuantitativas, normalmente distribuidas, seleccione el coeficiente de correlación de Pearson. Si los datos no están normalmente distribuidos o tienen categorías ordenadas, seleccione la tau-b de Kendall o de Spearman, que miden la asociación entre órdenes de rangos. (p. 207)

Mientras que Guillén (2015) afirma que

El coeficiente de correlación de Spearman es una técnica no paramétrica. El coeficiente de correlación de Spearman denotado por rs se utiliza cuando alguna de las variables es ordinal o incluso dicotómica o para variables cuantitativas con muestras pequeñas, es decir, en el caso del coeficiente de Spearman, se utilizan los rangos de los valores en lugar de los valores originales, por lo tanto, es adecuado para muestras pequeñas puesto que es robusto a la presencia de «outliers» (valores extremos). (p. 79)

Por lo tanto, para establecer si existe una correlación entre estas dos variables, es pertinente usar la correlación de Spearman, ya que una de las variables no cumple con el requisito de normalidad (Webster, 2000).

Hipótesis nula: el Número de noticias donde son mencionados los candidatos políticos en la prensa digital y la Votación electoral municipal Lima Metropolitana 2018 no están correlacionados estadísticamente.
Hipótesis alternativa: el Número de noticias donde son mencionados los candidatos políticos en la prensa digital y la Votación electoral municipal Lima Metropolitana 2018 sí están correlacionados estadísticamente.

De la tabla 3 observamos que los indicadores Menciones de los candidatos políticos en la prensa digital y Número de noticias donde son mencionados los candidatos políticos en la prensa digital están correlacionados con la Votación electoral municipal Lima Metropolitana 2018. Además, el rho de Spearman es de 0,933 y el valor $p$ es 0,000 menor al nivel de significancia; es decir, la correlación entre las variables mencionadas es significativa. Por lo tanto, se rechaza la hipótesis nula y se acepta la hipótesis alternativa planteada líneas arriba.

De acuerdo con la tabla de Interpretaciones más comunes de los valores de correlación (Pearson y Spearman) presentada por Akoglu (2018), una correlación con un valor de correlación superior a 0,7 es muy fuerte.

\section{Presentación de resultados}

En la figura 1 se muestra, mediante barras, las cantidades que se obtienen para el valor $p$ y la correlación de Spearman y entre el indicador Número de noticias donde son mencionados los candidatos políticos en la prensa digital y la Votación electoral municipal Lima Metropolitana 2018. Como ya se ha mencionado, estos valores indican una correlación muy alta entre los dos indicadores, lo que prueba la hipótesis del presente trabajo.

\section{CONCLUSIONES}

Los diarios digitales están altamente correlacionados (correlación muy fuerte) con la votación electoral; esta asociación se ha demostrado con el indicador Número de noticias donde son mencionados los candidatos políticos en la prensa digital con el resultado de las elecciones.

Asimismo, este resultado se ha demostrado para las elecciones municipales de Lima Metropolitana

Tabla 3. Correlación de Spearman entre el Número de noticias donde son mencionados los candidatos políticos en la prensa digital y la Votación electoral municipal Lima Metropolitana 2018.

\begin{tabular}{|c|c|}
\hline $\begin{array}{l}\text { Rho de Spearman: el Número de noticias donde son mencionados los candidatos políticos en la prensa digital y la Votación } \\
\text { electoral municipal Lima Metropolitana 2018 (\%) }\end{array}$ \\
\hline \multicolumn{2}{|c|}{ Correlaciones } \\
\hline Rho de Spearman & 0,933 \\
\hline Valor $p$ & 0,000 \\
\hline
\end{tabular}

Fuente: elaboración propia. 


\section{Lima Metropolitana 2018. Diarios digitales y Votación electoral}

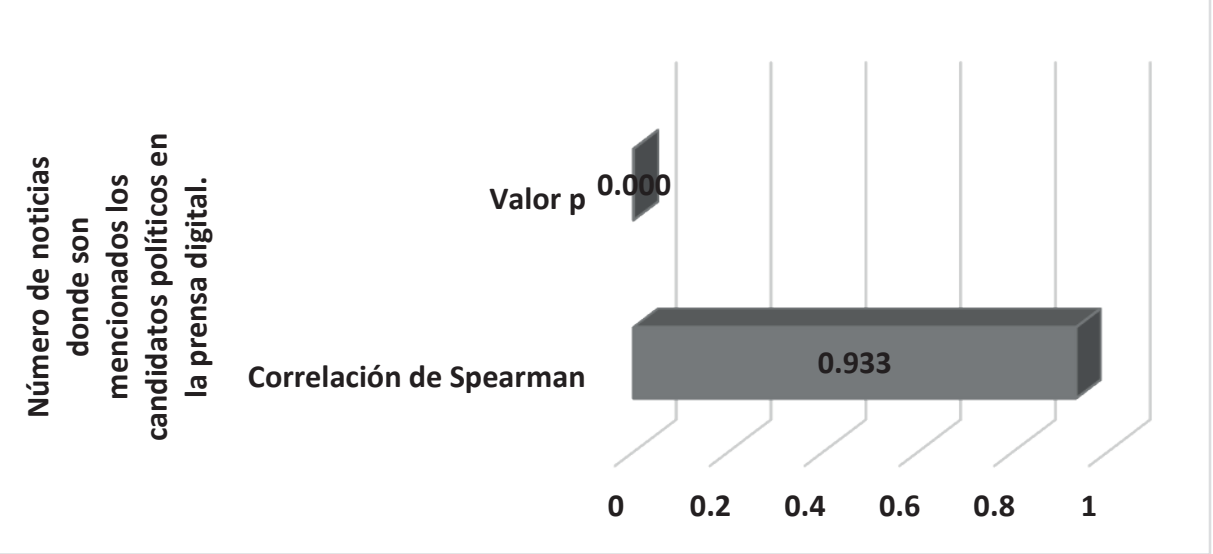

Figura 1. Resultado de la correlación entre Menciones de los candidatos políticos en diarios digitales y Votación electoral municipal Lima Metropolitana 2018.

Fuente: elaboración propia.

2018, y se puede afirmar que la cobertura periodística que hacen las empresas periodísticas de determinados candidatos estará asociada a la votación electoral que obtengan dichos candidatos. Por ejemplo, se observa que las menciones que se hicieron en la campaña electoral del candidato Humberto Lay fueron muy pocas y que fue uno de los candidatos con más baja votación el día de las elecciones.

Debemos considerar que la prensa —en particular, la prensa digital - podría construir una opinión pública. Por ese motivo, se ha identificado a la prensa como el cuarto poder del Estado; en este trabajo se pone en evidencia, una vez más, este poderío. Es clara la asociación entre la cobertura de los medios de comunicación y la decisión que toma la ciudadanía en las urnas.

\section{REFERENCIAS BIBLIOGRÁFICAS}

[1] Akoglu, H. (2018). User's guide to correlation coefficients. Turkish Journal of Emergency Medicine, 18(3), 91-93.

[2] Bernal, C. (2010). Metodología de la investigación. Bogotá, Colombia: Pearson Educación.

[3] Daza, C. (2010). Análisis de las estrategias de marketing político de Álvaro Uribe Vélez durante sus campañas electorales de 2002 y 2006 y durante el ejercicio de su gobierno presidencial en Colombia. (Tesis de maestría). Pontificia Universidad Javeriana, Bogotá.
[4] El Comercio (26 de agosto del 2014). ¿Qué partido es considerado el más corrupto en el Perú? Recuperado de https://elcomercio.pe/ politica/partidos/partido-considerado-corruptoperu-356463.

[5] El Comercio (22 de abril del 2018). La corrupción, el principal problema del Perú. Recuperado de https://elcomercio.pe/ politica/corrupcion-principal-problema-perunoticia-513999.

[6] El Comercio (11 de enero del 2019). Los ilustres peruanos que lucharon contra la corrupción en el Perú. Recuperado de https://elcomercio. pe/luces/libros/impreso-ilustres-peruanoslucharon-corrupcion-peru-noticia-596624.

[7] El Comercio (29 de enero del 2019). El Perú mantiene un alto índice de percepción de corrupción. Recuperado de https://elcomercio. pe/politica/peru-mantiene-alto-indicepercepcion-corrupcion-noticia-602105.

[8] Guillén, O. (2015). Guía de SPSS 22 para elaboración de trabajos de investigación científica. Málaga, España: Universidad de los Pueblos de Europa.

[9] Hernández, R.; Fernández, C. y Baptista, P. (2010). Metodología de la investigación. México, D. F., México: McGraw-Hill / Interamericana Editores S. A.

[10] INEI (27 de marzo del 2018). Aumentan hogares que tienen servicio de internet de octubre a diciembre de 2017. Recuperado de https:// 
www.inei.gob.pe/prensa/noticias/aumentanhogares-que-tienen-servicio-de-internet-deoctubre-a-diciembre-de-2017-10671/.

[11] Levin, R y Rubin, D. (2014). Estadística para Administración y Economía. México, D. F., México: Pearson Educación.

[12] Milton, J. (2001). Estadística para Biología y Ciencias de la Salud. Madrid, España: McGraw-Hill / Interamericana Editores S. A.

[13] Monje, C. (2011). Metodología de la investigación cuantitativa y cualitativa. Neiva, Colombia: Universidad Surcolombiana.

[14] ONPE (2 de noviembre del 2018). ONPE publica resultados de Lima al 100\%. Recuperado de http://www.onpe.gob.pe/sala-prensa/notasprensa/onpe-publica-resultados-lima-al-100/.
[15] Pérez, C. (2001). Técnicas estadísticas con SPSS. Madrid, España: Prentice Hall.

[16] Tamayo, M. (2003). El proceso de la investigación científica. México, D. F., México: Limusa-Noriega Editores.

[17] Webster, A. (2000). Estadística aplicada a los negocios y la economía. Bogotá, Colombia: McGraw-Hill / Interamericana Editores S. A.

[18] Weiers, R. (1986). Investigación de mercados. México, D. F., México: Prentice Hall. 


\section{Impact of digital newspapers on electoral vote}

David Paz PANduro

\section{ABSTRACT}

The purpose of this article is to demonstrate that the appearance of political candidates in digital newspapers has a positive correlation with electoral vote. The indicator of the independent variable used is the number of news stories in the digital press in which political candidates appear; whereas the indicator of the dependent variable is the percentage of the electoral vote obtained by the political candidates. The electoral process analyzed was the 2018 Lima Metropolitana Municipal Election. In addition, the Google search engine was used, where the basic command (search operator) site was used to search the websites of 19 Peruvian digital newspapers for the appearances of candidates in a semi-manual way. Finally, it was concluded that digital newspapers have a very strong correlation with electoral vote, as the Spearman's rho coefficient obtained was 0.933 .

Keywords: Digital marketing; electoral vote; political marketing; digital political marketing.

\section{INTRODUCTION}

There is a problem of perception in Peru. According to the survey by CPI mentioned in the newspaper El Comercio (2014, August 26), political parties are corrupt; the APRA, Perú Posible and Fuerza Popular are the political parties that obtained the highest percentage of the answer to the question "Which political party is the most corrupt?". According to the survey by El Comercio (2018, April 22) and Ipsos Perú, corruption now tops the list of problems in the country. This situation had not been seen since 2010, during the second Aprista administration. Peru has moved down in the global corruption perception ranking as one of the most corrupt countries in the world and shares $105^{\text {th }}$ place with EI Salvador, East Timor and Zambia (El Comercio, 2019, January 29). Although the official name of 2019 in Peru is "Year of the fight against corruption and impunity", the perception in the minds of Peruvians is the issue of this study.

The following lines intend to show how digital newspapers, which are digital marketing tools, are associated with electoral marketing tools, in other words, with the results at the ballot box, which are the final judgment given by a people on political candidates and the parties that support them. Therefore, the contribution of this study is to demonstrate, statistically, that digital newspapers are associated with electoral vote and to identify which indicator shows this correlation.

This article was prepared to assist political parties in the elaboration of their marketing strategies; therefore, this research has a Business to Business (B2B) approach, considering the author as a company that offers this information to political parties, which are currently run as private companies. Thus, political campaign managers (project managers) will be able to orientate their strategies to increase the indicators that are correlated with vote at the ballot box, as it is demonstrated that if these indicators increase, electoral vote increases as well.

Industrial Engineer from the Universidad Nacional Mayor de San Marcos. He is currently head of Multiservicios Paz Panduro S. A. C. (Lima).

E-mail: paz.david.anibal@gmail.com 
In his book Historia de la corrupción en el Perú (2013), Peruvian historian Alfonso Quiroz mentions various historical figures who fought against illegality, noteworthy among which are Antonio de Ulloa, Domingo Elías and Manuel Gonzáles Prada (El Comercio, 2019, January 11). Through digital newspapers, it will be possible to show the electorate that political parties have returned to their roots and have been inspired by modernity. It will also prove that their values are still strong, that there are leaders like these anti-illegality fighters, that the political institution is above the mistakes of the presidential candidates, who ultimately are only leaders that can be replaced and that the ideology of the party can be preserved, which is important.

Political marketing has been used in several presidential campaigns around the world with positive results. Political campaigns around the world are designing "estrategias en las que los electores son analizados como consumidores, sus preferencias, sus necesidades también, su personalidad y sus valores son convertidos en estadísticas que permiten a un grupo de orientadores políticos ofrecer un producto deseable, una idea o un candidato que responda a la demanda de los electores" [strategies in which voters are analyzed as consumers, their preferences, needs, personality and values are turned into statistics that allow a group of political advisors to offer a desirable product, an idea or candidate that responds to the demand of voters] (Daza, 2010, pp. 9-10).

\section{METHODOLOGY}

Monje (2011) states that "cuando el objetivo principal del investigador es comprender el comportamiento humano en contextos naturales, el diseño será de manera inevitable no experimental o de carácter observacional" [when the main objective of the researcher is to understand human behavior in natural contexts, the design will inevitably be non-experimental or observational] (p. 24). Likewise, Hernández et al. (2010) define "investigación no experimental como estudios que se realizan sin la manipulación deliberada de variables y en los que solo se observan los fenómenos en su ambiente natural para después analizarlos" [non-experimental research as studies that are conducted without the deliberate manipulation of variables and in which phenomena are observed only in their natural environment and then analyzed] (p. 149). Therefore, this research has a non-experimental design, as the research variables are not manipulated and the appearances of candidates in digital newspapers can only be modified by those in charge of managing the campaign of political candidates.

Similarly, according to Tamayo (2003):

A la investigación aplicada se le denomina también activa o dinámica, y se encuentra íntimamente ligada a la anterior, ya que depende de sus descubrimientos y aportes teóricos. Busca confrontar la teoría con la realidad. Es el estudio y aplicación de la investigación a problemas concretos, en circunstancias y características concretas. Esta forma de investigación se dirige a su aplicación inmediata y no al desarrollo de teorías. [Applied research is also called active or dynamic research and it is closely related to the former, as it depends on its discoveries and theoretical contributions. It aims at comparing theory against practice. It is the study and application of research to specific problems in specific circumstances and characteristics. This type of research is intended for its immediate application, instead of the development of theories.] (p. 43)

This is an applicative research study, since it is oriented to solve problems, to its immediate application; it is also correlational, because it will measure the degree of statistical correlation between the political marketing tool and electoral vote.

The research will also have quantitative characteristics. In that respect, Bernal (2010) defines that:

[EI] método cuantitativo o método tradicional se fundamenta en la medición de las características de los fenómenos sociales, lo cual supone derivar de un marco conceptual pertinente al problema analizado, una serie de postulados que expresen relaciones entre las variables estudiadas de forma deductiva. Este método tiende a generalizar y normalizar resultados. [[The] quantitative or traditional method is based on the measurement of the characteristics of social phenomena, which implies deducing a series of postulates that express relationships between the variables studied in a deductive way from a conceptual framework relevant to the problem analyzed.] (p. 60)

The approach is hypothetical-deductive, because it intends to develop a theory. First, basic hypotheses are formulated, and then their consequences are deduced with the help of the underlying formal theories (Tamayo, 2003). The hypothesis of this study is 
that correlation exists between digital newspapers and electoral vote, which has been validated by means of inferential statistical techniques.

\section{Unit of analysis}

The object of study is the 2018 Lima Metropolitana municipal electoral process, in Lima (Peru). The presence of political candidates in digital newspapers who are vying for the office of mayor will be analyzed, as well as the relationship of this presence with the electoral vote they achieved in the process.

\section{Study population}

For this research, all the candidates participating in the 2018 Lima Metropolitana Municipal Election have been chosen as the population. In addition, this process was chosen because it is the most recent in Peru and because, according to information in the INEI press release (2018, March 27), 32.9\% of Peruvians and $56.7 \%$ of the citizens of Lima Metropolitana accessed the Internet in the first half of 2018; in other words, more than half of the voters had access to the Internet.

\section{Sample size}

The sample to demonstrate the relationship between the Appearances of political candidates in digital newspapers and Electoral vote is comprised of the nine candidates to the office of mayor: Renzo Reggiardo, Daniel Urresti, Ricardo Belmont, Luis Castañeda Pardo, Jorge Muñoz, Humberto Lay, Esther Capuñay, Alberto Beingolea and Enrique Cornejo.

\section{Sample selection}

Non-probability sampling was used in this research, since the candidates for the analysis have been selected considering their chances of winning the office of mayor, instead of in a random way. Similarly, the vote of the candidates selected for this study covers $81.55 \%$ of the electoral vote, that is to say, it is a judgment sample (Weiers, 1986).

En las muestras no probabilísticas, la elección de los elementos no depende de la probabilidad, sino de causas relacionadas con las características de la investigación o de quien hace la muestra. Aquí el procedimiento no es mecánico ni con base en fórmulas de probabilidad, sino que depende del proceso de toma de decisiones de un investigador o de un grupo de investigadores $y$, desde luego, las muestras seleccionadas obedecen a otros criterios de investigación. [In non-probability samples, the selection of items does not depend on probability, but on causes related to the characteristics of the research or on who takes the sample. Here the procedure is neither mechanical nor based on probability formulas, but depends on the decision-making process of a researcher or a group of researchers and, of course, the selected samples that follow other research criteria.] (Hernández et al., 2010, p. 176)

The sample of digital newspapers selected for this study consisted of the following nineteen digital newspapers: altavoz.pe, americatv.com.pe, andina.pe, atv.pe, canaln.pe, capital.com.pe, elcomercio.pe, diariocorreo.pe, elpopular.pe, enlinea.pe, exitosanoticias.pe, expreso.com.pe, gestion.pe, larepublica.pe, panamericana.pe, peru21.pe, rpp. pe, trome.pe and wayka.pe. The newspapers were chosen on the basis of Google Alerts reports, where they appeared mentioning the political candidates competing for the office of mayor for Lima Metropolitana in the final part of the electoral process.

\section{Data collection techniques}

The study mainly used systematic observation and statistical testing. In addition, to analyze the number of appearances of political candidates in digital newspapers in the last days of the Lima Metropolitana municipal election campaign, Google Alerts was used, given that it provides all mentions of the keywords (in this case, the names of the nine candidates) entered by a user. These appearances on the Internet were obtained close to the day of the municipal election (from September 23 to October 6,2018 , after the municipal debate). Nineteen digital newspapers were selected using this information.

Then, to tabulate the number of news stories per digital newspaper that mentions each of the political candidates, Google's search engine was used using the basic command site (search operator), which searches a particular term or keyword in websites. In this case, it made it possible to search for political candidates' appearances in the news stories on each website of the selected digital newspapers.

Then, in order to obtain the number of news stories from digital newspapers that mention a candidate, care was taken not to duplicate the news and a semi-manual counting was performed. In a similar manner, only the most relevant results of the Google search were used in the analysis, omitting very similar entries. 
The vote count obtained by the political candidates studied was acquired from the ONPE website on November 2, 2018.

\section{DATA ANALYSIS AND INTERPRETATION}

For data processing, the research study relies on the software built to execute basic and advanced statistical functions: Minitab. Microsoft Excel was also used for charts and other personalized graphics. In addition, books by Levin and Rubin (2004) and Webster (2000) were consulted for the interpretation of statistics results, along with Minitab.

\section{RESULTS Y DISCUSSION}

It will be demonstrated that the independent variable Appearances of political candidates in the digital press is statistically correlated, at a high degree, with the dependent variable Electoral vote for the 2018 Lima Metropolitana Municipal Election.

The number of news stories in which the political candidates competing for the office of mayor for Lima
Metropolitana 2018 appear was obtained from the sample of nineteen digital newspapers (see Table 1).

Correlation between indicators Appearances of political candidates in the digital press and Electoral vote for the 2018 Lima Metropolitana Municipal Election

First, it must be established whether indicators Appearances of political candidates in the digital press and Electoral vote for the 2018 Lima Metropolitana Municipal Election have a normal distribution. Thus, the following hypotheses are proposed:

Null hypothesis no. 1: Electoral vote for 2018 the Lima Metropolitana Municipal Election is normally distributed.

Alternative hypothesis A1: Electoral vote for the 2018 Lima Metropolitana Municipal Election is not normally distributed.

Null hypothesis no. 2: Indicator Appearances of political candidates in the digital press and Number of news stories where political candidates appear in

Table 1. Indicator of Appearances of political candidates for the 2018 Lima Metropolitana Municipal Election in digital newspapers.

\begin{tabular}{|l|c|c|}
\hline Candidate & Electoral vote (\%) & $\begin{array}{c}\text { Number of news stories where political candidates appear in the } \\
\text { digital press }\end{array}$ \\
\hline Jorge Muñoz & 36.03 & 781 \\
\hline Daniel Urresti & 19.69 & 1340 \\
\hline Renzo Reggiardo & 8.87 & 1019 \\
\hline Alberto Beingolea & 4.46 & 327 \\
\hline Ricardo Belmont Cassinelli & 3.89 & 706 \\
\hline Luis Castañeda Pardo & 2.58 & 303 \\
\hline Esther Capuñay & 2.04 & 207 \\
\hline Enrique Cornejo & 2.01 & 203 \\
\hline Humberto Lay & 1.98 & 158 \\
\hline
\end{tabular}

Source: Prepared by the author.

Table 2. Saphiro-Wilk normality test for Electoral vote for the 2018 Lima Metropolitana Municipal Election and for Number of news stories where political candidates appear in the digital press for the 2018 Lima Metropolitana Municipal Election.

\begin{tabular}{|c|c|c|c|c|c|c|}
\hline \multicolumn{7}{|c|}{ Normality tests } \\
\hline & \multicolumn{3}{|c|}{ Kolmogorov-Smirnova } & \multicolumn{3}{|c|}{ Shapiro-Wilk } \\
\hline & Statistic & df & Sig. & Statistic & df & Sig. \\
\hline Electoral vote (\%) & 0.321 & 9 & 0.008 & 0.691 & 9 & 0.001 \\
\hline $\begin{array}{l}\text { Number of news stories where political candidates appear in the digital } \\
\text { press }\end{array}$ & 0.266 & 9 & 0.067 & 0.870 & 9 & 0.122 \\
\hline
\end{tabular}

a: Lilliefors significance correction.

Source: Prepared by the author. 
the digital press for the 2018 Lima Metropolitana Municipal Election are distributed normally.

Alternative hypothesis A2: Indicator Appearances of political candidates in the digital press and Number of news stories where political candidates appeared on the digital press for Lima 2018 Metropolitana Municipal Election are not normally distributed.

The Saphiro-Wilk normality test was used as recommended by Guillén (2015), who mentions that "debemos tener presente que se usa Kolgomorov Smirnov porque la muestra es mayor a 50, de no ser asi se usa Shapiro Wilk" [we must keep in mind that the Kolgomorov Smirnov test is used when the sample is greater than 50 , otherwise Saphiro-Wilk is used] (p. 88) and by Milton (2001), who emphasizes that "el test de Shapiro-Wilk es adecuado cuando hay pocos datos" [the Saphiro-Wilk test is appropriate when there is little data] (p. 640).

Therefore, from the SPSS report observed in Table 2, the p-value for Electoral vote for the 2018 Lima Metropolitana Municipal Election has a level of significance of less than 0.05 . In that regard, the null hypothesis is rejected in the first case (no. 1) and the first alternative hypothesis (A1), Electoral vote for the 2018 Lima Metropolitana Municipal Election is not normally distributed, is accepted.

The p-value for Number of news stories where political candidates appear in the digital press has a level of significance greater than 0.05 . Consequently, the null hypothesis in the second case (no. 2) is accepted and the second alternative hypothesis (A2) is rejected. Thus, the Number of news stories where political candidates appear in the digital press and the indicator of variable Appearances of political candidates in the digital press are normally distributed.

Regarding the correlation coefficients, Pérez (2001) states as follows:

Para las variables cuantitativas, normalmente distribuidas, seleccione el coeficiente de correlación de Pearson. Si los datos no están normalmente distribuidos o tienen categorías ordenadas, seleccione la tau-b de Kendall o de Spearman, que miden la asociación entre órdenes de rangos. [For the normally distributed quantitative variables, select Pearson's correlation coefficient. If the data is not normally distributed or has ordered categories, select Kendall or Spearman's tau-b, which measure the association between order ranges.] (p. 207)

Whereas Guillén (2015) states the following:

El coeficiente de correlación de Spearman es una técnica no paramétrica. El coeficiente de correlación de Spearman denotado por rs se utiliza cuando alguna de las variables es ordinal o incluso dicotómica o para variables cuantitativas con muestras pequeñas, es decir, en el caso del coeficiente de Spearman, se utilizan los rangos de los valores en lugar de los valores originales, por lo tanto, es adecuado para muestras pequeñas puesto que es robusto a la presencia de "outliers» (valores extremos). [Spearman's correlation coefficient is a nonparametric technique. The Spearman correlation coefficient, denoted by rs, is used when any of the variables is ordinal or even dichotomous or for quantitative variables with small samples, i.e., in the case of Spearman's coefficient, ranges of values are used instead of the original values, therefore it is appropriate for small samples since it is robust to the presence of "outliers" (extreme values).] (p. 79)

Accordingly, in order to establish whether there is correlation between these two variables, it is appropriate to use Spearman's correlation, as one of the variables does not meet the normality criteria (Webster, 2000).

Null hypothesis: Number of news stories where political candidates appear in the digital press and Electoral vote for the 2018 Lima Metropolitana Municipal Election are not statistically correlated.

Table 3. Spearman's correlation between Number of news stories where political candidates appear in the digital press and Electora vote for 2018 Lima Metropolitana Municipal Election.

\begin{tabular}{|c|c|}
\hline $\begin{array}{c}\text { Spearman's rho: Number of news stories where political candidates appear in the digital press and Electoral vote for } 2018 \\
\text { Lima Metropolitana Municipal Election (\%) }\end{array}$ \\
\hline \multicolumn{2}{|c|}{ Correlations } \\
\hline Spearman's rho & 0.933 \\
\hline p-value & 0.000 \\
\hline
\end{tabular}

Source: Prepared by the author. 
Alternative hypothesis: Number of news stories where political candidates appear in the digital press are distributed normally and Electoral vote for the 2018 Lima Metropolitana Municipal Election are statistically correlated

From Table 3 it can be observed that the indicators Appearances of political candidates in the digital press and Number of news stories where political candidates appear in the digital press are correlated with Electoral vote for the 2018 Lima Metropolitana Municipal Election. In addition, Spearman's rho is 0.933 and the $p$-value is 0.000 , lower than the significance level; in other words, correlation between the mentioned variables is significant. Therefore, the null hypothesis is rejected and the alternative hypothesis mentioned above is accepted.

According to the interpretation table of the most common correlation values (Pearson \& Spearman) presented by Akoglu (2018), a correlation with a correlation value greater than 0.7 is very strong.

\section{RESULTS}

Figure 1 shows, using bars, the p-value obtained and the Spearman's correlation coefficient between variables Number of news where the political candidates appear in the digital press and Electoral vote for the 2018 Lima Metropolitana Municipal Election. As already mentioned, these values indicate a very high correlation between the two variables, which demonstrate the hypothesis of this research study.

\section{CONCLUSIONS}

Digital newspapers are highly correlated (very strong correlation) with electoral vote; this association has been demonstrated with the indicator Number of news stories where political candidates appear in the digital press and the results of the election.

In addition, this result has been demonstrated for the 2018 Lima Metropolitana Municipal Election, and it can be said that the journalistic coverage of certain candidates by news companies will be associated with the electoral vote obtained by those candidates. For example, it can be seen that the appearances made by the electoral campaign of candidate Humberto Lay in the press were very few and that he was one of the candidates with the lowest electoral vote on election day.

It is important to note that the press-particularly, the digital press-could shape public opinion. For this reason, the press has been identified as the fourth power of the State; in this research, said power, is again, evident. There is a clear association between media coverage and the decision made by the people at the ballot box.

\section{REFERENCES}

[1] Akoglu, H. (2018). User's guide to correlation coefficients. Turkish Journal of Emergency Medicine, 18(3), 91-93.

\section{Lima Metropolitana 2018. Digital newspapers and electoral vote}

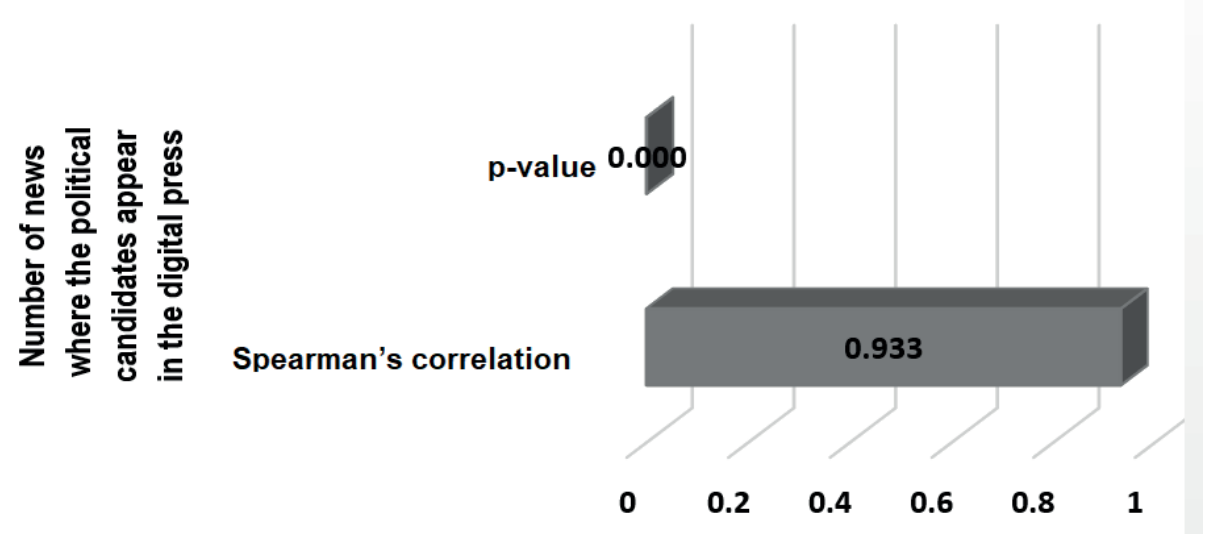

Figure 1. Correlation result between Appearances of political candidates in the digital and Electoral vote for the 2018 Lima Metropolitana Municipal Election.

Source: Prepared by the author. 
[2] Bernal, C. (2010). Metodología de la investigación. Bogotá, Colombia: Pearson Educación.

[3] Daza, C. (2010). Análisis de las estrategias de marketing político de Álvaro Uribe Vélez durante sus campañas electorales de 2002 y 2006 y durante el ejercicio de su gobierno presidencial en Colombia. (Tesis de maestría). Pontificia Universidad Javeriana, Bogotá.

[4] El Comercio (26 de agosto del 2014). ¿Qué partido es considerado el más corrupto en el Perú? Recuperado de https://elcomercio.pe/ politica/partidos/partido-considerado-corruptoperu-356463.

[5] El Comercio (22 de abril del 2018). La corrupción, el principal problema del Perú. Recuperado de https://elcomercio.pe/ politica/corrupcion-principal-problema-perunoticia-513999.

[6] El Comercio (11 de enero del 2019). Los ilustres peruanos que lucharon contra la corrupción en el Perú. Recuperado de https://elcomercio. pe/luces/libros/impreso-ilustres-peruanoslucharon-corrupcion-peru-noticia-596624.

[7] El Comercio (29 de enero del 2019). El Perú mantiene un alto índice de percepción de corrupción. Recuperado de https://elcomercio. $\mathrm{pe/politica/peru-mantiene-alto-indice-}$ percepcion-corrupcion-noticia-602105.

[8] Guillén, O. (2015). Guía de SPSS 22 para elaboración de trabajos de investigación científica. Málaga, España: Universidad de los Pueblos de Europa.
[9] Hernández, R.; Fernández, C. y Baptista, P. (2010). Metodología de la investigación. México, D. F., México: McGraw-Hill / Interamericana Editores S. A.

[10] INEI (27 de marzo del 2018). Aumentan hogares que tienen servicio de internet de octubre a diciembre de 2017. Recuperado de https:// www.inei.gob.pe/prensa/noticias/aumentanhogares-que-tienen-servicio-de-internet-deoctubre-a-diciembre-de-2017-10671/.

[11] Levin, R y Rubin, D. (2014). Estadística para Administración y Economía. México, D. F., México: Pearson Educación.

[12] Milton, J. (2001). Estadística para Biología y Ciencias de la Salud. Madrid, España: McGraw-Hill / Interamericana Editores S. A.

[13] Monje, C. (2011). Metodología de la investigación cuantitativa y cualitativa. Neiva, Colombia: Universidad Surcolombiana.

[14] ONPE (2 de noviembre del 2018). ONPE publica resultados de Lima al $100 \%$. Recuperado de http://www.onpe.gob.pe/sala-prensa/notasprensa/onpe-publica-resultados-lima-al-100/.

[15] Pérez, C. (2001). Técnicas estadísticas con SPSS. Madrid, España: Prentice Hall.

[16] Tamayo, M. (2003). El proceso de la investigación científica. México, D. F., México: Limusa-Noriega Editores.

[17] Webster, A. (2000). Estadística aplicada a los negocios y la economía. Bogotá, Colombia: McGraw-Hill / Interamericana Editores S. A.

[18] Weiers, R. (1986). Investigación de mercados. México, D. F., México: Prentice Hall. 